\title{
Określanie lokalnych stref koncentracji naprężeń w wyrobach przemysłu maszynowego - brakujące ogniwo w systemie badań nieniszczących
}

\author{
Stress-strain state control of main gas pipelines \\ - the lacking link in assessment of their reliability
}

\section{Streszczenie}

Coraz więcej specjalistów zdaje sobie sprawę, że faktyczny stan naprężenia i odkształcenia (SNO) gazociągów magistralnych (GM) oraz rurociągów gazowych stacji kompresorowych określa nie tylko niezawodność materiałowa rur, ale również niezawodność izolacji, niezależnie od technologii jej nakładania i składu jakościowego.

Konieczność badań nieniszczących (NDT) SNO rurociągów gazowych powstaje w przypadku rozmaitego rodzaju naruszeń w gruntach (osuwisk, sezonowych zmian temperatury itp.).

W referacie zwrócono uwagę na konieczność prowadzenia badań nieniszczących gazociągów magistralnych podczas ich remontu i przedłużania okresu eksploatacyjnego. Wykazano, że brak badań nieniszczących SNO GM podczas ich remontu kapitalnego wraz z wymianą izolacji powoduje, iż uszkodzenia lokalne rozwijające się w strefach maksymalnej koncentracji naprężeń pozostają niewykryte i dopuszczone do dalszej eksploatacji na długi czas.

Wysiłki większości specjalistów zajmujących się badaniami NDT są skoncentrowane na ocenie średnich naprężeń objętościowych w rurociągu. Jednocześnie wiadomo, że podstawowymi źródłami postawania i rozwoju uszkodzeń rurociągów są lokalne strefy koncentracji naprężeń (SKN).

Do oceny stanu rurociągów gazowych w lokalnych SKN proponowana jest metoda magnetyczna pamięci metalu (MPM). Metoda ta nie wymaga żadnych prac przygotowawczych i różni się od innych metod NDT tym, że pokazuje poziom koncentracji naprężeń, tzn. wskazuje stopień niebezpieczeństwa wykrytych wad.

Przedstawiono możliwości metody MPM dotyczące określania uszkodzeń korozyjno-naprężeniowych na wczesnym etapie ich rozwoju.

\section{Abstract}

A growing number of experts realize that the actual stress-strain state (SSS) of main gas pipelines (MG) and compressor station gas line piping determines not only the pipe metal's reliability but also the insulation reliability regardless of its application technology and qualitative composition.

The necessity of gas pipelines SSS non-destructive testing (NDT) occurs at various irregularities in soils (landslides, seasonal temperature fluctuations).

The paper highlights the necessity of MG SSS control during their repairs and extension of service lifetime. It is demonstrated that the lack of MG SSS non-destructive testing (NDT) during their overhaul with insulation replacement leads to the fact that local developing defects in the maximum stress concentration zones remain undetected and are admitted for further long-term operation.

Efforts of the majority of experts involved in practical SSS control are focused on the assessment of mean, volumetric stresses in the pipeline. At the same time it is known that the major sources of pipeline damages occurrence and development are local stress concentration zones (SCZs).

It is proposed to use the metal magnetic memory (MMM) method to assess the pipelines' condition in local SCZs. The MMM method does not require any preparatory works during the inspection and differs from other NDT methods by the fact that it indicates the stress concentration level, i.e. it indicates the degree of the detected defects hazard.

Capabilities of the MMM method for detecting of stress corrosion damages at an early stage of their development are presented.

Prof. Anatolij A. Dubov - Energodiagnostika, Moskwa. 
Podstawowymi źródłami uszkodzeń podczas eksploatacji wyrobów przemysłu maszynowego są obszary stref koncentracji naprężeń (SKN), które powstają pod wpływem działania obciążeń roboczych przede wszystkim w miejscach występowania wad pochodzenia hutniczego i technologicznego (tzw. karbów). Wady produkcyjne, hutnicze i technologiczne $w$ wielu przypadkach powodują powstawanie w lokalnych strefach wyrobu wysokiego poziomu naprężeń szczątkowych (NS). Kontrola NS wyrobów w poszczególnych przedsiębiorstwach prowadzona jest w sposób wyrywkowy. Kontrolowany jest przy tym średni (objętościowy) poziom NS, a strefy lokalne NS powodowanych przez wady wewnętrzne metalu z zasady nie podlegają kontroli i są przepuszczane. Poza tym nie wiadomo, gdzie takie strefy lokalne są rozmieszczone, ani w jaki sposób można je wykryć.

Zazwyczaj podczas diagnostyki wstępnej nie jest wykonywana kontrola pod kątem obecności naprężeń szczątkowych. Z wymienionych powodów już podczas pierwszych lat eksploatacji wyrobów pod obciążeniem roboczym następuje ich naturalne brakowanie, które jest większości w przypadków wynikiem ich uszkodzeń. Wady technologiczne i hutnicze, wywołując wysoki poziom NS w strefach lokalnych wyrobów, przy niekorzystnych połączeniach z naprężeniami eksploatacyjnymi, powodują przyśpieszony rozwój uszkodzeń.

Tradycyjne metody badań nieniszczących (NDT) ukierunkowane są na poszukiwanie i wykrywanie wad znajdujących się przeważnie na powierzchni wyrobów. Wady wewnętrzne odlewów, różnego rodzaju niejednorodności struktury, a także technologiczne wady produkcyjne (wady spawania, walcowania, gięcia, obróbki cieplnej i inne), z powodu braku w większości zakładów produkcyjnych $100 \%$ kontroli jakości wyrobów, a także wskutek niedoskonałości stosowanych metod NDT, pozostają w wyrobach nie wykryte. Jednocześnie same normy brakowania $w$ metodach NDT stosowanych u producentów wyrobów są ukierunkowane na wykrywanie wad o rozmiarach wielokrotnie przekraczających rozmiary wad hutniczych. Na przykład, zgodnie z normami badań ultradźwiękowych rur austenitycznych, dopuszczalne wady mają wymiary o długości nie przekraczającej $25 \mathrm{~mm}$ oraz szerokości i głębokości maks. 0,3 mm. Jak wykazuje praktyka, wady hutnicze o mniejszych wymiarach, na które działają obciążenia robocze, stanowią także źródła uszkodzeń eksploatacyjnych. W warunkach eksploatacji wyrobów praktycznie wszystkie metody NDT ukierunkowane są na poszukiwanie wszelkiego rodzaju nieciągłości, których wymiary znacznie przekraczają wymiary wad wywołujących rozwój uszkodzeń.

Dlatego właśnie należy zauważyć, że brak kontroli NS w celu określenia obszarów koncentracji naprężeń w miejscach występowania wad struktury wyrobów, zarówno u producenta, jak i podczas eksploatacji, stanowi brakujące ogniwo w systemie badań NDT gotowych wyrobów, co znacznie obniża ich niezawodność.

$\mathrm{Na}$ rysunku 1 pokazano schemat organizacji NDT wyrobów przemysłu maszynowego, jaki obecnie ukształtował się w zakładach produkcyjnych i podczas eksploatacji. Z rysunku 1 wynika, że kontrola wyrobów polega na defektoskopii, bez oceny poziomu koncentracji naprężeń w miejscach wykrytych nieciągłości i wad struktury. Linią przerywaną na rysunku zaznaczono brakujące ogniwo w systemie NDT.

Należy zauważyć, że obecnie, gdy urządzenia i konstrukcje w większości dziedzin przemysłu osiągają stan zużycia fizycznego i obliczeniowego, a brak jest środków materialnych na ich masową wymianę, coraz istotniejsze znaczenie mają badania nieniszczące i diagnostyka techniczna. W takich warunkach zwiększa się rola metod ekspresowych NDT zapewniających $100 \%$ kontroli urządzeń i wykrycia lo-
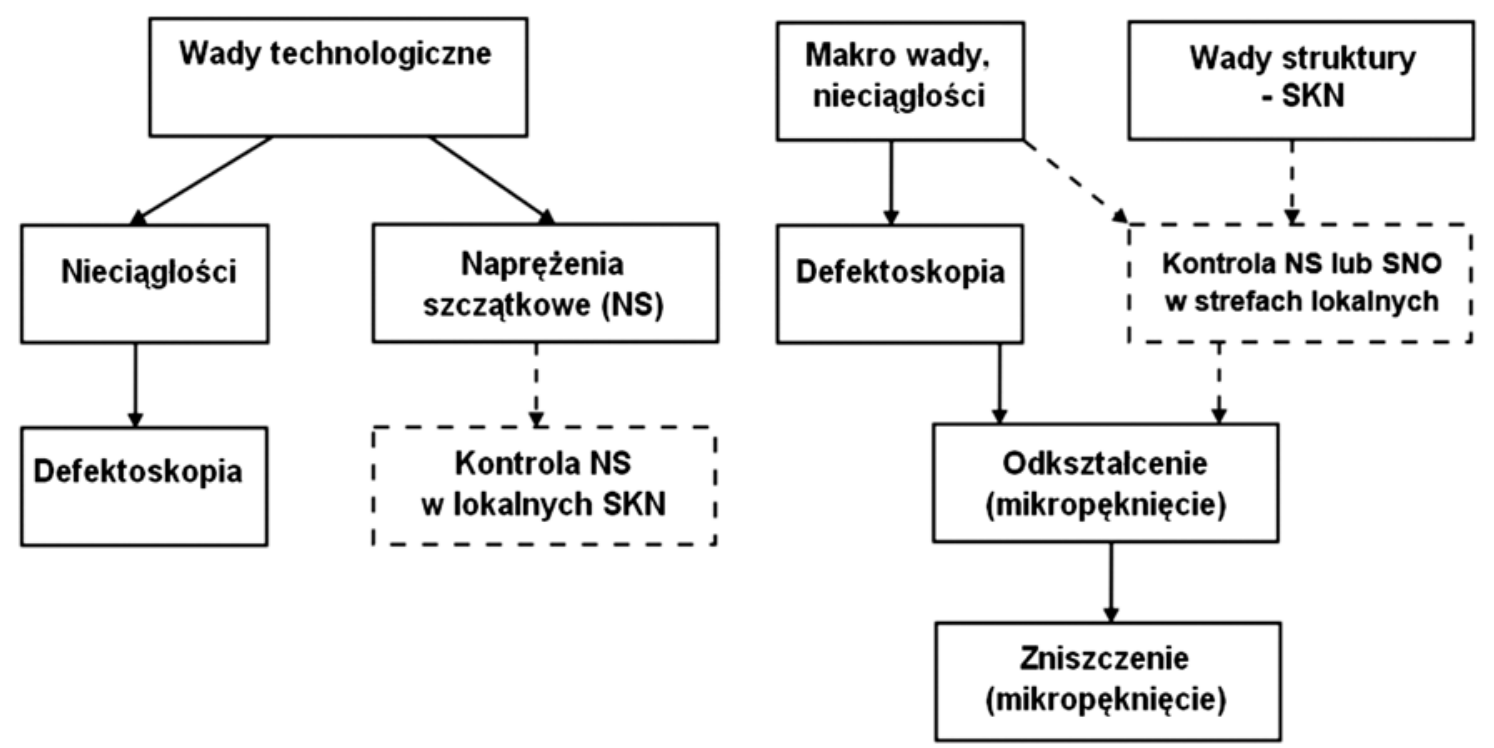

Rys. 1. Schemat organizacji badań nieniszczących wyrobów przemysłu maszynowego u producenta i w trakcie eksploatacji Fig. 1. Schematic organization of non-destructive testing of mechanical engineering at the factory and during operation. 
kalnych SKN, w których moga nastapić uszkodzenia podczas dalszej eksploatacji urządzeń technicznych.

W 2008 r. weszła w życie w Rosji norma państwowa GOST R 53006-2008 Ocena trwałości obiektów potencjalnie niebezpiecznych na podstawie metod ekspresowych. Wymagania ogólne.

Do metod ekspresowych należą metody pasywne badań NDT, wykorzystujące energię wewnętrzną metalu konstrukcji:

- metoda emisji akustycznej (AE);

- metoda magnetycznej pamięci metalu (MPM),

- metoda termowizyjna.

Metody te mają obecnie najszersze zastosowanie praktyczne we wczesnej diagnostyce uszkodzeń urządzeń i konstrukcji. Zasadnicza różnica takiego podejścia do oceny trwałości polega na wykonywaniu 100\% badań obiektu kontroli (OK), z wykrywaniem wszystkich potencjalnie niebezpiecznych stref koncentracji naprężeń (SKN), stanowiących źródła powstawania uszkodzeń podczas eksploatacji urządzeń.

W nowej normie państwowej GOST R 53006-2008 uwzględnia się odbicie następujące podstawowe założenia:

- schemat strukturalny określania pozostałego okresu zaproponowano z położeniem nacisku na współczesne metody diagnostyki technicznej;

- proponowane jest wykonywanie obliczeń kontroInych wytrzymałości z oceną pozostałego okresu dla SKN wyrobów pozostających w eksploatacji, z uwzględnieniem faktycznych właściwości strukturalno-mechanicznych metalu, uwidocznionych podczas badań;

- uwzględnione są zalecenia normy państwowej GOST R 52330-2005 Badania nieniszczące. Kontrola stanu naprężenia-odkształcenia obiektów przemysłowych i transportowych. Wymagania ogólne.
Podczas realizacji normy GOST R 53006-2008 wydaje się, że w większości przypadków możliwe jest, bez skomplikowanych obliczeń kontrolnych wytrzymałości, dokonywanie ekspertyzy trwałości na podstawie kompleksowych badań urządzeń oraz określanieczasu jego bezawaryjnej eksploatacji. Dla danego urządzenia możliwe jest opracowanie dokładniejszej metodyki oceny okresu, z uwzględnieniem specyficznych właściwości i wymagań obowiązujących w danej dziedzinie przemysłu.

Coraz szersze rozpowszechnienie praktyczne przy określaniu lokalnych SKN w wyrobach nowych i znajdujących się w eksploatacji uzyskuje metoda magnetycznej pamięci metalu (MPM), opracowana przez firmę OOO Energodiagnostika w Moskwie. Metoda MPM jest ujęta w normach rosyjskich i międzynarodowych.

Zgodnie z GOST R ISO 24497-1-2009 Badania nieniszczące. Metoda magnetycznej pamięci metalu. Terminy i określenia, metoda MPM jest metodą badań nieniszczących, opartą na rejestracji i analizie rozkładu własnych magnetycznych pól rozproszonych (WMPR), powstających w strefach koncentracji naprężeń (SKN) i niejednorodności strukturalnej wyrobów. Jednocześnie WMPR odzwierciedlają nieodwracalną zmianę namagnesowania w kierunku działania naprężeń maksymalnych wskutek obciążeń roboczych (zewnętrznych), historii obciążeń, lokalnej zmiany tekstury i faz materiału oraz istniejących w materiałach defektów struktury.

Metoda MPM w zasadniczy sposób różni się od wszystkich znanych metod magnetycznych badań NDT tym, że przy jej zastosowaniu nie jest wymagane sztuczne magnesowanie wyrobuwystarczy namagnesowanie naturalne oraz pamięć magnetyczna metalu w obszarach faktycznych odkształceń i zmian strukturalnych [1].

Metoda MPM nie wymaga podczas prowadzenia ba- a)

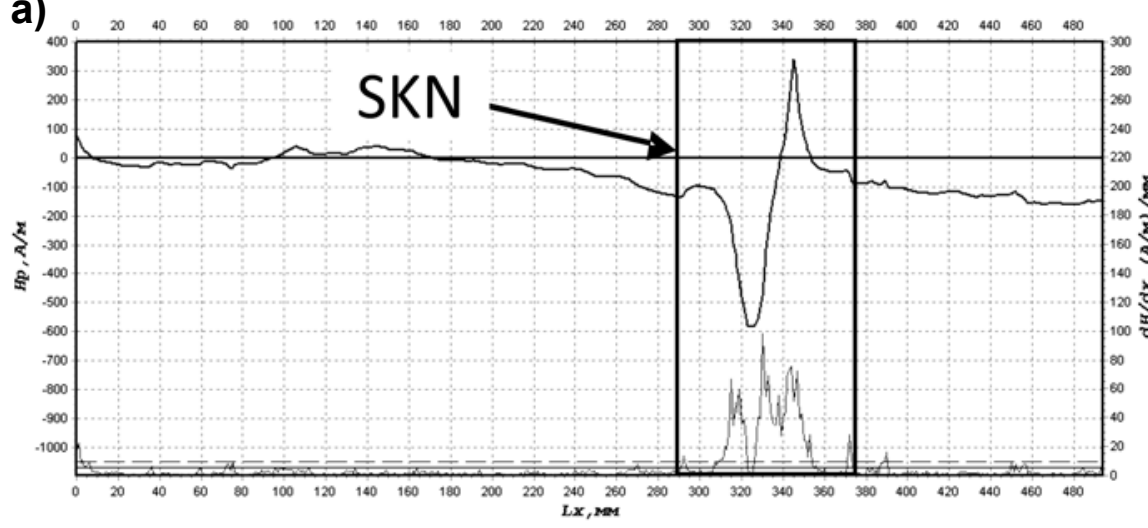

b)

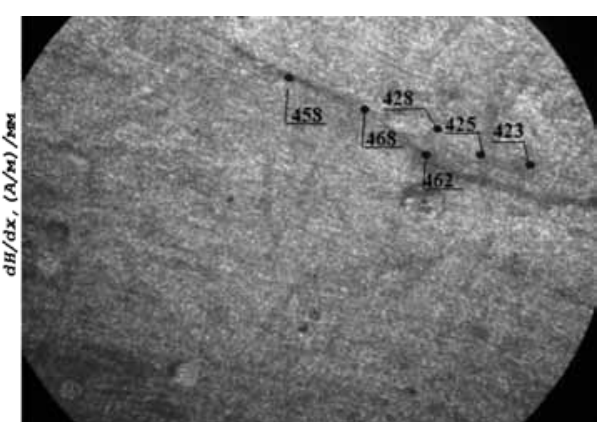

Rys. 2. Wyniki badań pręta $\varnothing 22 \mathrm{~mm}$ (stal. 05Х16Н4Д2Б-Т13), z którego wykonany jest wał pompy odśrodkowej o napędzie elektrycznym (ECN), wyprodukowany przez spółkę OOO PK Boriec w Lebedianie: a) magnetogram rozkładu normalnej składowej własnego pola magnetycznego rozproszenia $H_{p}$ i jego gradientu $d H / d x$, zarejestrowany w strefie koncentracji naprężeń (SKN) podczas skanowania czujnikiem przyrządu wzdłuż jednej z tworzących pręta nr 2204; b) stan strukturalny metalu pręta nr 2204 w przekroju pokrywającym się z SKN. Cyframi oznaczone są wartości twardości mikroskopowej wzdłuż linii wady hutniczej i poza nią

Fig. 2. The results of the rod $\varnothing 22 \mathrm{~mm}$ (St. 05Х16Н4Д2Б-Т13), which is made of a centrifugal pump shaft electric motor (ECN), produced in the production base of the company OOO PK Borie" in Lebed: a) the distribution of the normal component of the magnetogram own magnetic field $H_{p}$ dispersion and its gradient $d H / d x$, registered in the zone of stress concentration (SKN) sensor scanning device along one of the forming rod No. 2204, b) as a structural metal rod No. 2204 in the section coincides with the Society. Numerals are marked with microscopic hardness values along the metallurgical defects and beyond 
dań żadnych prac przygotowawczych i różni się od innych metod NDT tym, że pokazuje poziom koncentracji naprężeń, tzn. wskazuje stopień niebezpieczeństwa wykrytych wad.

W dalszym ciągu rozpatrzymy możliwości metody MPM podczas diagnostyki wyrobów nowych i używanych w celu określenia lokalnych SKN, czyli źródeł rozwoju uszkodzeń.

Na rysunku 2 przedstawiono wyniki badań nowego pręta Ø22 mm (05X16Н4Д2БТ13), z którego wykonany jest wał pompy odśrodkowej o napędzie elektrycznym (ECN), wyprodukowanej w bazie produkcyjnej spółki OOO PK Boriec w Lebedianie.

$\mathrm{Na}$ rysunku 2a pokazano magnetogram rozkładu normalnej składowej własnego pola magnetycznego rozproszenia $H_{p}$ i jego gradientu $d H / d x$, zarejestrowany w strefie koncentracji naprężeń (SKN) podczas skanowania czujnikiem przyrządu wzdłuż jednej z tworzących pręta $\mathrm{nr} 2204$. Na rysunku 2b przedstawiono stan strukturalny metalu pręta nr 2204 w przekroju pokrywającym się z SKN. Cyframi oznaczone są wartości twardości mikroskopowej wzdłuż linii wady hutniczej i poza nią.

$\mathrm{Na}$ rysunku 3 przedstawiono wyniki badań metodą MPM łopatki wirnika nowej turbiny wodnej. Na rysunku $3 a$ widać rozkład pola magnetycznego $\mathrm{H}_{\mathrm{p}}$ i jego gradientu $d H / d x$, zarejestrowany podczas badań wzdłuż powierzchni zewnętrznej łopatki. W części dolnej magnetogramu zaznaczona jest strefa SKN, charakteryzująca się lokalnymi zmianami gradientu pola. Na rysunku 3b pokazano wady odlewu wykryte w głębi metalu po dokonaniu przekroju łopatki w miejscu SKN, ustalonej za pomocą metody MPM na powierzchni zewnętrznej.

$\mathrm{Na}$ rysunku 4 przedstawiono wyniki badań metodą MPM rury $\varnothing 42 \times 7 \mathrm{~mm}$ ze stali $10 \times 13 Г 12 Б С 2 \mathrm{H} 2 Д 2$, wyciętej z nowego grodziowego przegrzewacza parowego kotła energetycznego. Na rysunku 4a pokazano magnetogram rozkładu własnego pola magnetycznego $\mathrm{H}_{\mathrm{p}}$ i jego gradientu $d H / d x$, zarejestrowany w SKN na jednej z tworzących rury. Mimo że omawiana rura jest wykonana ze stali nierdzewnej, która w stanie wyjściowym (po wyprodukowaniu) powinna być praktycznie niemagnetyczna, to z powodu naruszenia dyscypliny technologicznej podczas jej produkcji, w strefie lokalnej wytworzyła się faza ferrytowa zarejestrowana podczas badań metodą MPM w postaci anomalii magnetycznej. Na rysunku 4b pokazane są pęknięcia wykryte na powierzchni wewnętrznej próbki rury wyciętej ze strefy anomalii magnetycznej odpowiadającej SKN.

Przedstawione na rysunkach $2 \div 4$ przykłady praktyczne zastosowania metody MPM w nowych wyrobach różnych przedsiębiorstw przemysłowych w sposób przekonujący pokazują wspólne braki w organizacji NDT u producentów. Wszystkie wymienione wyroby przechodziły przez system NDT, jaki w dzisiejszych czasach istnieje w zakładach produkcyjnych. Jednak, jak wspomniano wyżej, obecniej w większości zakładów produkcyjnych brak jest kontroli dotyczącej

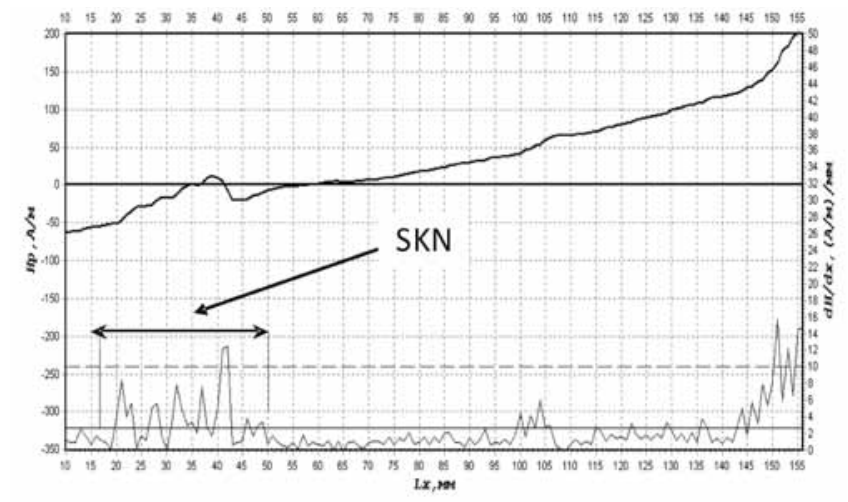

-

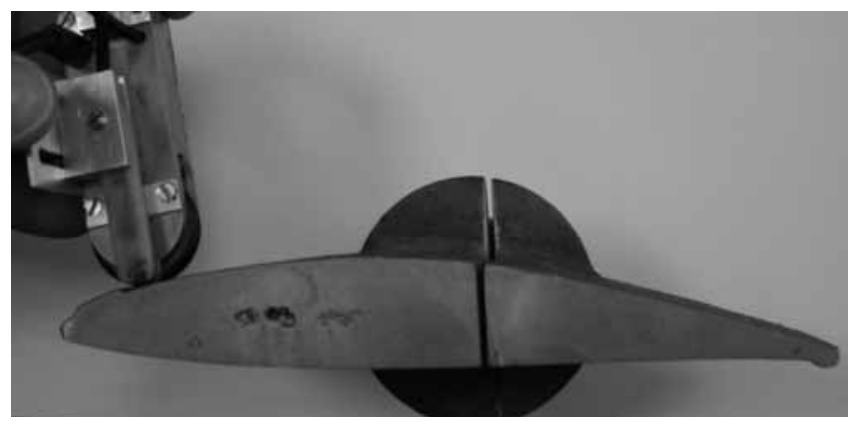

Rys. 3. Wyniki badań metodą MPM łopatki wirnika nowej turbiny wodnej: a) rozkład pola magnetycznego $H_{p}$ i jego gradientu $d H / d x$, zarejestrowany podczas badań wzdłuż powierzchni zewnętrznej łopatki; b) wady odlewu wykryte w SKN po dokonaniu przekroju łopatki Fig. 3. The study by MPM new turbine rotor blades of water: a) the distribution of the magnetic field and its gradient $H p d H / d x$, recorded during surveys along the outer surface of the blade; b) casting defects detected in the Society after the section of blade.

wykrywania wad metalu znajdujących się poza normowanymi zakresami czułości stosowanych metod i środków kontroli. Zastosowanie metody MPM, która wykrywa wady hutnicze i technologiczne w postaci anomalii magnetycznych odpowiadających lokalnym strefom koncentracji naprężeń, pozwoliłoby zapewnić 100\% kontrolę wyrobów nawet w przypadku produkcji seryjnej.

Podczas eksploatacji wyrobów przemysłu maszynowego podstawowymi źródłami rozwoju uszkodzeń są lokalne SKN - miejsc ich powstawania praktycznie nie można przewidzieć za pomocą metod obliczeniowych. Zastosowanie metody MPM daje taką możliwość, dzięki wykonywaniu $100 \%$ kontroli rozmaitych podzespołów urządzeń, wczesnego wykrywania stref lokalnych o maksymalnej koncentracji naprężeń.

W celu klasyfikacji anomalii magnetycznych charakteryzujących SKN ze względu na stopień ich niebezpieczeństwa zgodnie $z$ metodyką przedstawioną w [2] dokonywane jest porównanie wszystkich anomalii magnetycznych ujawnionych w danym podzespole na podstawie wartości gradientu pola $d H / d x$.

Dla podzespołów urządzeń jednego typu określana jest, na podstawie badań laboratoryjnych i przemysłowych, wartość graniczna gradientu pola, przy której powstaje mikropęknięcie i rozpoczyna się rozwój uszkodzenia. 

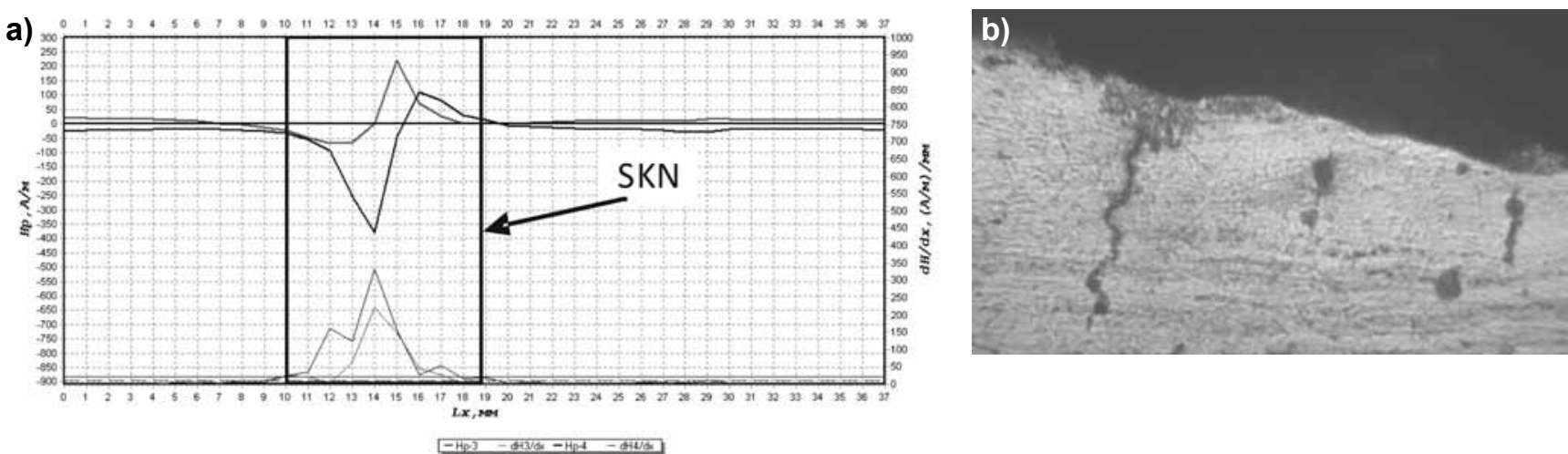

Rys. 4. Wyniki badań rury $42 \times 7$ ze stali $10 \times 13 Г 12 Б С 2 \mathrm{H} 2 Д 2$, wyciętej z nowego grodziowego przegrzewacza parowego kotła energetycznego: a) magnetogram rozkładu własnego pola magnetycznego $H$ i jego gradientu $d H / d x$, zarejestrowany w strefie koncentracji naprężeń (SKN) na jednej z tworzących rury; b) pęknięcia wykryte na powierzchni wewnętrznej próbki rury wyciętej z SKN, ujawnionej za pomocą metody MPM Fig. 4. Results $42 \times 7$ steel pipe $10 Х 13 Г 12 Б С 2 \mathrm{H} 2 Д 2$ cut from the bulkhead new power boiler steam superheater: a) magnetogram decomposition own magnetic field $H$ and its gradient $d H / d x$, registered in the zone of stress concentration (SKN) on one of the forming tube; b) detected crack on the inner surface of the sample cut from SKN tube, using the method disclosed MPM.

a)

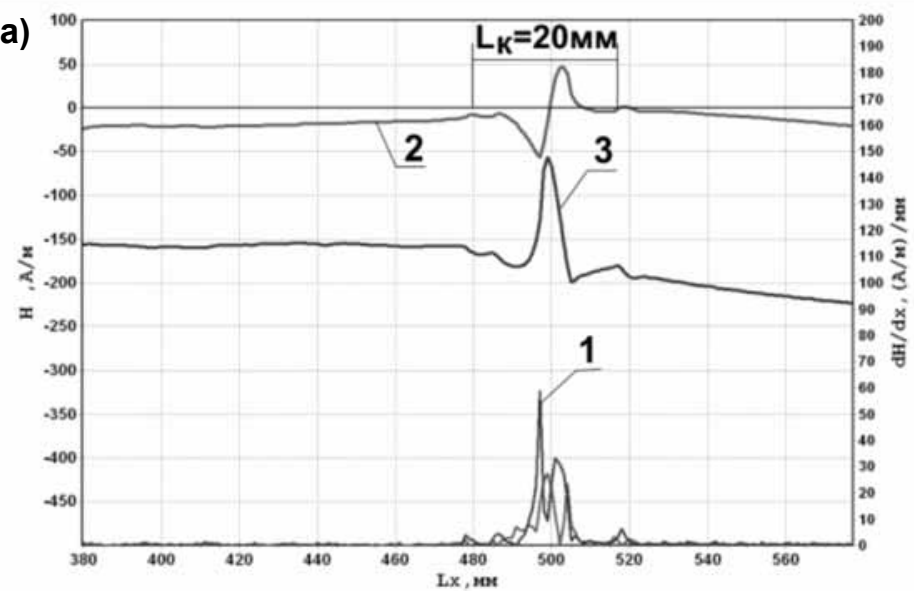

b)

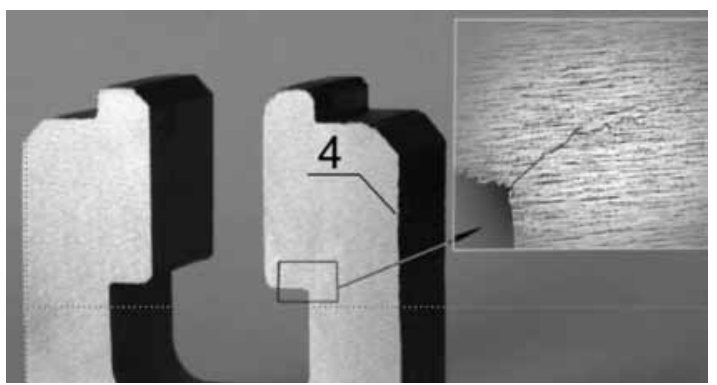

c)

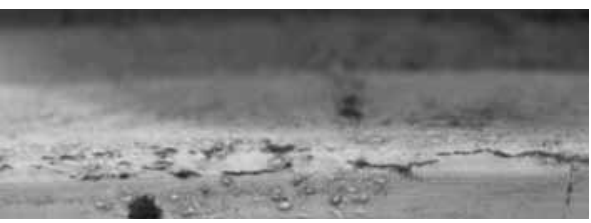

Rys. 5. Wyniki kontroli wieńca tarczy stopnia turbiny parowej $120 \mathrm{MW}$ : a) fragment magnetogramu zarejestrowany na powierzchni zewnętrznej wieńca tarczy z przesunięciem w górę o ok. $45^{\circ}$ od miejsca położenia pęknięcia na powierzchni wewnętrznej tarczy; b) miejsce ujawnionego pęknięcia o głębokości ok. $2 \mathrm{~mm}$; c) położenie pęknięcia wzdłuż powierzchni wewnętrznej wieńca tarczy o długości ok. $20 \mathrm{~mm}(l)$; 1 - maksymalna wartość gradientu $d H / d x ; 2$ - rozkład składowej stycznej pola $H$; 3 - rozkład składowej normalnej pola H; 4 - strefa kontroli metodą MPM od strony zewnętrznej tarczy przed wycięciem fragmentu

Fig. 5. Results control wheel rim level of the steam turbine of $120 \mathrm{MW}$ : a) fragment magnetogramu registered on the outer surface of the rim wheel with shift upwards by about 45 degrees from the location of cracks on the surface of the inner disc, b) the place of the disclosed crack of depth of $2 \mathrm{~mm}, \mathrm{c}$ ) location of cracks along the inner surface of the wheel rim with a length of about 20 mm $\left(l_{k}\right), 1-$ maximum value of the gradient $d H / d x, 2$ - Distribution of the tangential component of the field $H, 3$ - Distribution of the normal component of the field $\mathrm{H}$, 4 - zone of control by MPM the outer side before cutting blade portion.

Zgodnie z określeniami przedstawionymi w niniejszym opracowaniu [3], sens fizyczny parametru magnetycznego $d H / d x$ polega na tym, że odzwierciedla on koncentrację (lub gęstość) energii magnetycznej w objętości wyrobu, uwarunkowanej gęstością energii odkształcenia.

Na rysunku 5 przedstawiono wyniki kontroli wieńca tarczy stopnia turbiny parowej $120 \mathrm{MW}$. Na rysunku 5a pokazano magnetogram zarejestrowany na powierzchni zewnętrznej wieńca tarczy. W części górnej magnetogramu pokazano rozkład składowej stycznej 2 i składowej normalnej 3 własnego pola magnetycznego $H$, a w części dolnej magnetogramu - rozkład gradientu pola wskutek tych składowych. Wartość maksymalna gradientu pola $55 \mathrm{~A} / \mathrm{m} / \mathrm{mm}$ (lub $55 \times 10^{3} \mathrm{~A} / \mathrm{m}^{2}$ ) okazała się w przybliżeniu równa wartości granicznej dla danej tarczy turbiny i dlatego w niniejszym przypadku została wykonana kontrola dodatkowa za pomocą badań ultradźwiękowych. Ustawienie przetwornika przyrządu do badań ultradźwiękowych (UT) na tarczy turbiny byłoprzy tym korygowane zgodnie z miejscem maksymalnej wartości gradientu pola. Podczas wykonywania UT w SKN na powierzchni wewnętrznej została zarejestrowana nieciągłość. Po wycięciu fragmentu tarczy na powierzchni wewnętrznej wykryto pęknięcie o głębokości $2 \mathrm{~mm}$ i długości $20 \mathrm{~mm}$ (rys. 5b i 5c).

Należy w tym miejscu zaznaczyć, że w dzisiejszych czasach, zgodnie z obowiązującą instrukcją [4], badania ultradźwiękowe tarcz turbin z łopatkami osadzonymi we wrębach w kształcie litery $T$ pod kątem 
ujawnienia pęknięć w rowkach wykonuje się z zastosowaniem specjalnie przygotowanych próbek, a samo badanie jest skomplikowanym zadaniem praktycznym. Podczas wykonywania badań ultradźwiękowych wieńca tarczy w połączeniu z metodą MPM, zamiast próbki standardowej można wykorzystać sposób porównywania sygnałów UT w strefie SKN, wykrytej wcześniej za pomocą metody MPM, jak również poza tą strefą.

Rozpatrzony przykład zastosowania metody MPM do wykrycia lokalnej SKN na wczesnym etapie rozwoju uszkodzenia w sposób przejrzysty pokazuje ważność i efektywność jej zastosowania w połączeniu z innymi metodami NDT. Doświadczenie w stosowaniu metody MPM wobec różnych urządzeń będących w długotrwałej eksploatacji w różnych branżach przemysłu pokazuje, że jedynie w 5 $\div 10 \%$ ogólnej objętości wyrobów metalowych osiągany jest stan graniczny (fizyczna granica wytrzymałości) i dochodzi do rozwoju uszkodzeń. Niestety, określenie tych lokalnych SKN - źródeł rozwoju uszkodzeń - za pomocą metod obliczeniowych jest utrudnione w warunkach diagnostyki bezpośrednio na obiektach przemysłowych. Jednak zadanie takie można rozwiązać przy wykorzystaniu metod wczesnej diagnostyki (metoda MPM, AE lub termowizja).

Podczas analizy mechanizmu uszkodzeń wyrobów najbardziej wartościowe jest określenie wielkości obszarów lokalnych (objętości, powierzchni, długości), przy których następuje stan graniczny metalu i samego wyrobu. Właśnie takie oto skomplikowane zadanie, które do tej pory było przedmiotem badań w mechanice uszkodzeń, przy wykorzystaniu metody MPM jest rozwiązywane bezpośrednio na urządzeniu podczas diagnostyki poszczególnych podzespołów

\title{
Literatura
}

[1] E. W. Lee: Magnetostriction and Magnetomechanical Effects Rep. Prog. Phys. 18 (1955) 184-229.

[2] Дубов А.А., Дубов Ал.А., Колокольников С.М. Метод магнитной памяти металла и приборы контроля: Учебное пособие. М.: ЗАО «Тиссо», 2008. 364 с.
[3] Власов В.Т., Дубов А.А. Физическая теория процесса «деформация-разрушение». Часть І. Физические критерии предельных состояний металла. М.: ЗАО «Тиссо», 2007. 517 c.

[4] Инструкция по продлению срока эксплуатации паровых турбин сверхпаркового ресурса. М.: ЦПТИ ОРГРЭС, 2004. $170 \mathrm{c}$.

\author{
Władysław Michnowski \\ Jarosław Mierzwa \\ Piotr Machała \\ Patryk Uchroński
}

\section{Automatyczne badanie kolejowych osi drążonych}

\section{Automatic tests of railway hollow axles}

W referacie przedstawiono automatyczny system do badania osi drążonych opracowany przez firmę ZBM ULTRA. $\mathrm{Na}$ początku zaprezentowano stan prawno-normatywny dotyczący badań ultradźwiękowych osi kolejowych (wymogi techniczne i sposoby ich egzekwowania wskazując na największe braki) oraz badanie osi drążonych przy rożnych poziomach zautomatyzowania. Kolejne rozdziały opisują opracowany system. Bazuje on na defektoskopie bezprzewodowym, który transmituje do komputera chwilowe wyniki badań, gdzie zostają one poddane dalszej obróbce (ocena i archiwizacja). Badanie kolejnych powierzchni osi odbywa się automatycznie poprzez zastosowanie silnika do przesuwania i obracania zespołu głowic badawczych. Rezultatem badania jest zbiór wskazań z każdego punktu powierzchni osi, który jest prezentowany w przystępnej formie graficznej. Bezprzewodowość umożliwia w znaczny sposób zredukowanie ilości przewodów i przez to uproszczenie konstrukcji całego systemu.
In the article automatic system for tests of hollow railway axles design by ZBM ULTRA was presented. In the beginning the authors made review of the legal status in ultrasonic tests of railway axles (its technical requirements and ways of their enforcement pointing the largest gaps) and tests of hollow axles on different levels of automation. Subsequent chapters describe the developed system. It is based on the wireless flaw detector, that transmits temporary results of tests to computer, where they are further processed (evaluation and archiving). Tests of subsequent areas of axles are carried out automatically using an engine for moving and rotation of ultrasonic probes. Result of the test is series of indications from every point of an axle's surface, which is presented in graphic form. Due to wireless connection an amount of wires may be reduced that leads to simplification of device construction.

Referat wygłoszono podczas 42. KKBN w Kołobrzegu 